\title{
Effects of temperature and sex steroids on sex ratio, growth, and growth-related gene expression in the Chinese giant salamander Andrias davidianus
}

\author{
Qiaomu Hu, Haifeng Tian, Hanbing Xiao* \\ Yangtze River Fisheries Research Institute, Chinese Academy of Fishery Sciences, Wuhan, Hubei 430223, PR China
}

\begin{abstract}
Andrias davidianus is one of most farmed amphibians owing to its palatability and nutritional value. In this transitional group between aquatic and terrestrial animals the effects of temperature and sex hormones on sex ratio and growth are not fully understood. Here, we quantified the sex dimorphism of $A$. davidianus growth with adult males approximately $30 \%$ larger than females, and for the first time determined the time of initiation of sex differentiation to be $\sim 98$ days post-hatching (dph). Mortality increased significantly with increased temperature, from $9.4 \%$ at $20^{\circ} \mathrm{C}$ to $40.6 \%$ at $28^{\circ} \mathrm{C}$. At temperatures $\geq 30^{\circ} \mathrm{C}$ we observed $100 \%$ mortality. The proportion of males was $66.1 \%$ at $28^{\circ} \mathrm{C}$, significantly higher than in the control group ( $\left.\mathrm{p}<0.05\right) .17 \alpha$ estradiol induced larval feminization and produced female bias of $81-100 \%$ at concentrations from $25 \mu \mathrm{g} \mathrm{l}^{-1}$ to $1000 \mathrm{\mu g} \mathrm{l}^{-1}$. However, sex bias was not observed in larvae exposed to $17 \alpha$-methyltestosterone at concentrations of $50 \mathrm{\mu g} \mathrm{l}^{-1}$ and $100 \mu \mathrm{g} \mathrm{l}^{-1}$. Additionally, growth characteristics at different temperatures showed that $28^{\circ} \mathrm{C}$ inhibited growth and $24^{\circ} \mathrm{C}$ promoted growth, reflecting the expression profile of growth-related genes $(G H, G H R$, and IGF-1). Sex steroids including $17 \beta-$ estradiol and $17 \alpha$-methyltestosterone significantly inhibited growth $(p<0.05)$. The results suggest that water temperature and sex steroids play a vital role in gonad differentiation and growth of A. davidianus.
\end{abstract}

KEY WORDS: Temperature $\cdot$ Sex steroids $\cdot$ Sex ratio $\cdot$ Growth $\cdot$ Andrias davidianus

\section{INTRODUCTION}

Sex is determined in vertebrates either genetically or environmentally, or via a combination of both factors (Nakamura 2009). In amphibians, when reared at natural temperatures, sex is generally genetically determined; however, environmental factors, including temperature, have been reported to affect sex (Wallace et al. 1999). Rearing at extremes of warm or cold temperatures may disturb sex differentiation and introduce a bias toward male or female. Among newts, Triturus cristatus larvae reared at temperatures of $14-26^{\circ} \mathrm{C}$ show a sex ratio of $\sim 50: 50$. However, when temperature was increased to $28^{\circ} \mathrm{C}$ or decreased to $13^{\circ} \mathrm{C}$, sex

${ }^{*}$ Corresponding author: xhb@yfi.ac.cn was significantly biased towards male and female, respectively (Wallace 1987). Pleurodeles waltl larvae reared at $32^{\circ} \mathrm{C}$ exhibited $\mathrm{ZW}$ female reversal to male (Dournon \& Houillon 1984, 1985). Similar phenomena have been observed in T. cristatus (Wallace \& Wallace, 2000) and the anurans Bufo vulgaris and Rana temporaria (Piquet 1930), R. sylvatica (Witschi 1929), and R. catesbeiana (Hsü et al. 1971). However, female reversal to male at high temperatures is not universal. Dournon \& Houillon (1985) showed high temperatures to have the opposite effect, inducing ZZ male $P$. poireti reversal to female (Dournon \& Houillon 1985).

Sex differentiation in amphibians is affected not only by temperature but also by sex steroids. In

๑ The authors 2019. Open Access under Creative Commons by Attribution Licence. Use, distribution and reproduction are unrestricted. Authors and original publication must be credited. 
amphibians, sex steroid induction of the sex differentiation is complicated and shows speciesdependent effects. Estrogen exposure is reported to produce all-female larvae of $P$. waltl (Gallien 1954), Hynobius nebulosus (Asayama \& Miyamori 1957), T. helviticus (Gallien \& Collenot 1960), and Ambystoma punctatum (Burns 1938, 1939). However, in $R$. esculenta, a high concentration of estrogen induced all-male offspring, while a low concentration produced all-female (Padoa 1936, 1943). Similar results have been observed in $R$. pipiens (Richards \& Nace 1978) and R. sylvatica (Hayes 1998). Androgen has been reported to masculinize larvae in some anuran species (Ohta 1987), but showed no effect on others (Hayes 1998). In urodeles, androgen showed no effect on some tested species and resulted in paradoxical feminization in others (Hayes 1998, Wallace et al. 1999).

Temperature and sex steroids influence the sex differentiation and sex ratio in amphibians, but do they affect growth as well? In $R$. chensinensis, the optimum temperature is reported as $10-20^{\circ} \mathrm{C}$ with growth affected outside this range (Wang \& Wang 2008). Growth rate of $R$. chensinensis increased with the temperature within a certain temperature range (Wang 2006), while extreme low temperature inhibited growth of $R$. chensinensis and B. gargarizans (Wang et al. 2005).

The Chinese giant salamander Andrias davidianus, considered a living fossil that experienced little outward change during the past 350 million years (Gao \& Shubin 2003), was historically widely distributed in many provinces of China (Yang et al. 2011). Due to environmental degradation and harvesting by humans the wild population has declined dramatically. Since the 1980s, the giant salamander has been classified as Endangered by the International Union for Conservation of Nature and Nature Resources. Due to its palatability and nutritional value the species is artificially bred and reared in China. To expand the market, the Chinese government has allowed trade of the giant salamander without a 'Manage and Exploit' or a 'Transport' license since 2015.

To determine whether temperature and sex steroids affect the sex ratio and growth, the present study (1) quantified sex growth dimorphism and (2) the developmental time of initiation of sex differentiation. The latter is important for inducing sex reversal to produce single-sex stock. Effects of temperature and sex hormones on Andrias davidianus larval sex ratio and growth were determined to aid in the captive rearing of these amphibians.

\section{MATERIALS AND METHODS}

\subsection{Gonad development analysis}

The experiments were carried out at the Zhejiang Yongqiang Chinese Giant Salamander Company (Jinhua, Zhejiang Province, PR China). To analyze the gonad development and identify the time at which sex differentiation began in Andrias davidianus, tissue containing the gonads was collected at 48, 62, 98 and 130 days post-hatching (dph), and gonads at 170,210, 270,360, and $545 \mathrm{dph}$ and at $3 \mathrm{yr}$ post-hatching. For each stage, 10-25 samples were fixed in $4 \%$ paraformaldehyde ( $\mathrm{pH} 7.5$ ) for $24 \mathrm{~h}$ and stored in $70 \%$ ethanol to identify the physiological sex by histology and to determine the time posthatching of initiation of sex differentiation.

\subsection{High temperature and sex hormone treatment}

Based on the onset of sex differentiation for $A$. davidianus, a total of 800 larvae before sex differentiation $(70 \mathrm{dph})$ were used to carry out the first-year experiment. Groups of 40 larvae in aquaria $(1 \times 1 \times$ $0.3 \mathrm{~m}^{3}$ ) were exposed to water at temperatures of 24 , 28 , and $32^{\circ} \mathrm{C}$, increasing by $0.5^{\circ} \mathrm{C} \mathrm{h}^{-1}$, with a group held at $20^{\circ} \mathrm{C}$ as control. The water temperature was controlled by the temperature control system (SOBO). Total mortality was seen in the $32^{\circ} \mathrm{C}$ group within $2 \mathrm{~d}$. A further 40 larvae exposed to water of $30^{\circ} \mathrm{C}$ exhibited total mortality within $5 \mathrm{~d}$, while the other groups showed no or few deaths. Two series of experiments at temperatures of 20,24 , or $28^{\circ} \mathrm{C}$ were performed up to 8 mo post-hatching. In the second year, 1200 larvae at $55 \mathrm{dph}$, in groups of 200, were placed in aquaria containing water at 20,24 , and $28^{\circ} \mathrm{C}$, with 2 aquaria per temperature level. Four series of experiments at each temperature were performed. Larvae were held until 8 mo post-hatching, after which salamanders were reared at ambient water temperature $\left(20^{\circ} \mathrm{C}\right)$.

400 larvae, 40 per first-year group, were used to assess effects of sex steroid exposure. Dry powders of $17 \beta$-estradiol (E) and 17 $\alpha$-methyltestosterone (MT) were dissolved in $95 \%$ ethanol and then diluted in water. Larvae were immersed daily for $10-12 \mathrm{~h}$ in water containing $\mathrm{E}$ at $25 \mathrm{\mu g} \mathrm{l}^{-1}$ (E1), $100 \mu \mathrm{g} \mathrm{l^{-1 }}$ (E2), $500 \mathrm{gg} \mathrm{l}^{-1}$ (E3), $1000 \mathrm{\mu g} \mathrm{l}^{-1}$ (E4) or MT at a concentration of $50 \mu \mathrm{g} \mathrm{l}^{-1}$ (MT1), $100 \mu \mathrm{g} \mathrm{l} \mathrm{l}^{-1}$ (MT2); the rest of the time the larvae were reared in water with no hormones. The trial was duplicated and continued to 8 mo post-hatching. 


\subsection{Mortality rate and sex ratio after high temperature and hormone treated}

At the conclusion of the temperature trial, mortality was combined to analyze survival rate of each group. After high temperature treatment, when the exposed salamanders had been reared at ambient temperatures for $18 \mathrm{mo}$, the gonads were removed, fixed in $4 \%$ paraformaldehyde ( $\mathrm{pH} 7.5)$ for $24 \mathrm{~h}$, and stored in $70 \%$ ethanol to identify the phenotypic sex. Gonads and gonadal tissue were dehydrated through an ethanol gradient and cleared in xylene, embedded in paraffin, and 5-6 $\mu \mathrm{m}$ sections were cut and stained with hematoxylin-eosin (H\&E), then examined under light microscopy (Olympus) to assess phenotypic sex.

Survival rate, mortality rate and sex ratio were calculated as follows:

$$
\begin{gathered}
\text { Mortality rate (MR) }(\%)=100 \times \mathrm{n}_{\mathrm{m}} / \mathrm{n} \\
\text { Average mortality rate (AMR) }(\%)=100 \times \mathrm{n}_{\mathrm{t}} / \mathrm{n}_{\mathrm{y}} \\
\text { Survival rate (SR) }(\%)=100 \times \mathrm{n}_{\mathrm{s}} / \mathrm{n} \\
\text { Female proportion (FP) }(\%)=100 \times \mathrm{N}_{\mathrm{f}} / \mathrm{N} \\
\text { Average female proportion (AFP) (\%) }=100 \times \mathrm{N}_{\mathrm{a}} / \mathrm{N}_{\mathrm{y}} \\
\text { Male proportion (MP) (\%) }=100 \times \mathrm{N}_{\mathrm{m}} / \mathrm{N} \\
\text { Average male proportion (AMP) }(\%)=100 \times \mathrm{N}_{\mathrm{b}} / \mathrm{N}_{\mathrm{y}}
\end{gathered}
$$

where $\mathrm{n}$ is the initial number of salamanders in each group $; \mathrm{n}_{\mathrm{m}}$ is the number of dead salamanders in each group $; \mathrm{n}_{\mathrm{t}}$ is the total number of dead salamanders at the same temperature from the 2 study years; $\mathrm{n}_{\mathrm{y}}$ is the total number of salamanders at the same temperature in the 2 years. $n_{\mathrm{s}}$ is the number of surviving salamanders in each group. $\mathrm{N}_{\mathrm{f}}$ is the number of females in each group; $\mathrm{N}_{\mathrm{m}}$ is the number of males in each group; $\mathrm{N}$ is the total number of salamanders in each group; $N_{a}$ is the total number of females in the 2 years; $N_{b}$ is the total number of males in the 2 years; $\mathrm{N}_{\mathrm{y}}$ is the total number of salamanders in the 2 years.

\subsection{Growth characteristic analysis}

To quantify sex dimorphism with respect to growth, 1173 broodstock salamanders with determined sex were weighed (age 9-12 yr), and the relative growth rate (RGR) was calculated according to the formula. Relative growth rate $\left(\mathrm{RGR}^{\circ} \%\right)=100 \times(\mathrm{W}-\mathrm{w}) / \mathrm{w}(\mathrm{W}$ : weight of males; w: weight of females). Andrias davidianus larvae were held at $18-20^{\circ} \mathrm{C}$ and fed on Chironomid larvae until 5 mo post-hatching, and then reared on chopped Hypophthalmichthys moli- trix 1 feeding $\mathrm{d}^{-1}$ ). Body weight and body length of at least 30 salamanders per stage were measured at 47 , $98,132,164,201,230,270,285,311,345$, and 353 $\mathrm{dph}$, as well as 18 and $30 \mathrm{mo}$, and $3.5 \mathrm{yr}$ post-hatching. At 98, 164, 201, 270, and 345 dph and 18 and 30 mo post-hatching, at least 3 individuals of each stage were killed after anaesthesia with MS222 according to Yangtze River Fisheries Research Institute Care Committee regulations (No. 2013001). The pituitary and brain were collected and stored at $-80^{\circ} \mathrm{C}$ for extraction of RNA.

To detect the influence of high temperature and hormones on growth, the body weights and body lengths of at least 30 salamanders from the above study were measured at 98,132, 164, 201, $230 \mathrm{dph}$ during the temperature exposure and at 270, 285, 311 , and $345 \mathrm{dph}$ without the temperature treatment; body weight and body length of at least 30 randomly selected salamanders from each group was measured at 132, 164, 201, 230 dph during the hormone treatment and at 285, 311, and $345 \mathrm{dph}$ without the hormone treated. To detect the expression profile, the pituitary and brain tissue were collected $201 \mathrm{dph}$ (during exposure) and $270 \mathrm{dph}$ (after exposure) in the temperature group and control group, respectively, and stored at $-80^{\circ} \mathrm{C}$ for RNA extraction.

\section{5. qRT-PCR analysis}

The RNA was extracted using the TRIZOL method from brain and pituitary at $201 \mathrm{dph}$ and $270 \mathrm{dph}$ from the high temperature treated group and control, respectively, and then the total RNA was treated with RNase-free DNasel (Tiangen) at $37^{\circ} \mathrm{C}$ for $1 \mathrm{~h}$. Finally, cDNA synthesis was carried out as described in Hu et al. (2017). Quantitative real-time PCR (qRT-PCR) was conducted on a QuantStudio 5 real-time PCR system (Applied Biosystems) as described in Hu et al. (2015). mRNA expression for each gene was analysed at least in 3 samples and independently in triplicate. Based on previous reports (Yang et al. 2010, Ji et al. 2011), the growth hormone gene $(G H)$ (pituitary), growth hormone receptor gene (GHR) (brain), and insulin-like growth factor-1 gene (IGF-1) (brain) were selected from the transcriptome database. Specific primers were designed according to the sequences (Table S1 in the Supplement at www.int-res.com/ articles/suppl/b028p079_supp.pdf), and beta-actin was used as the internal reference to evaluate the relative expression level. The reaction was performed according to the QuantScript RT kit (Takara) manufacturer's instructions with $10 \mu$ SYBR Premix 


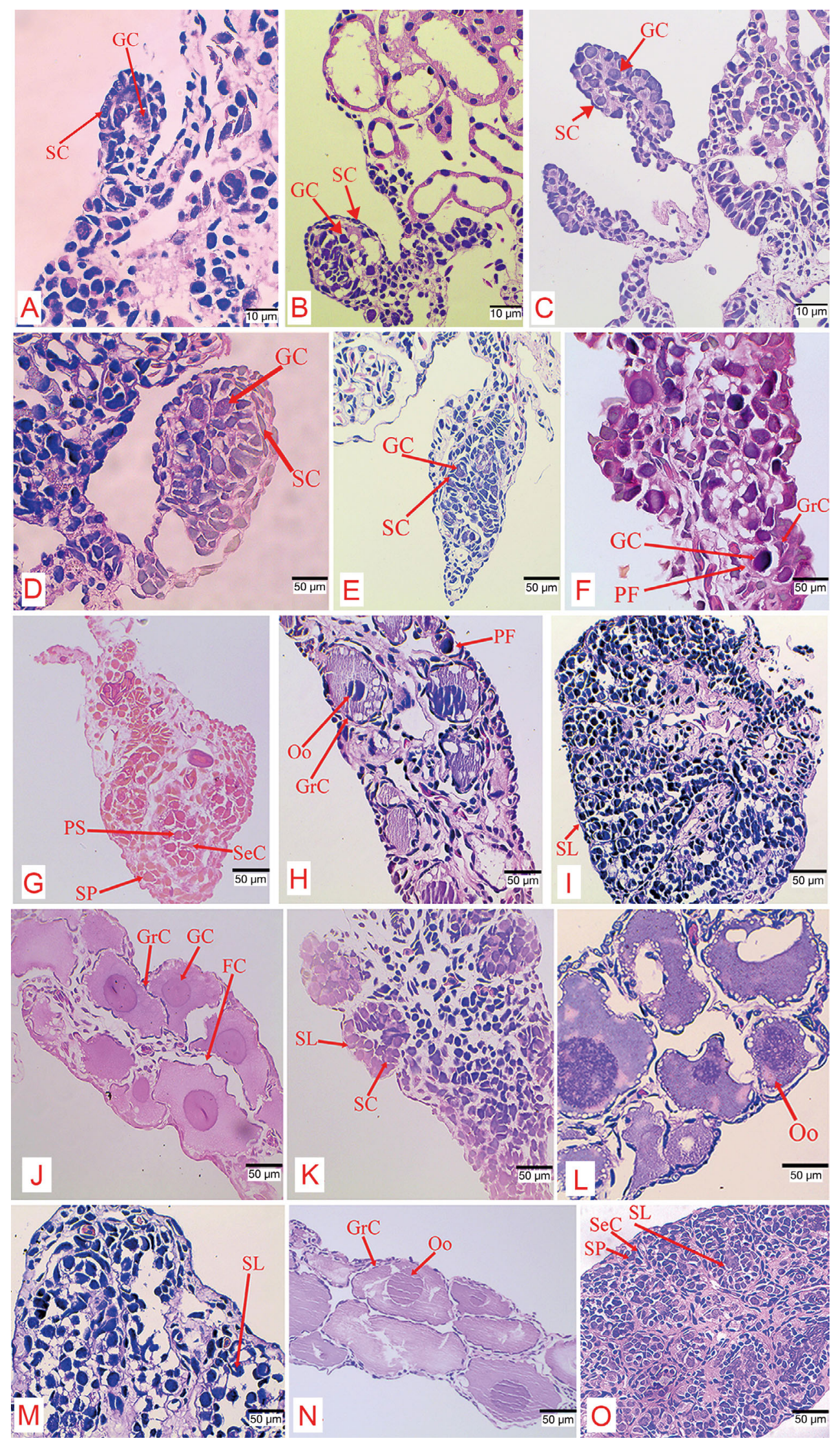


Ex Tap, $0.4 \mu \mathrm{l}$ ROX reference dye, $0.4 \mu \mathrm{l}$ of each primer and $1 \mu \mathrm{l}$ cDNA and made up to $20 \mu \mathrm{l}$ using double-distilled water. The reaction was carried out as follows: $30 \mathrm{~s}$ at $95^{\circ} \mathrm{C}$, followed by 40 cycles of $5 \mathrm{~s}$ at $95^{\circ} \mathrm{C}$ and $34 \mathrm{~s}$ at $60^{\circ} \mathrm{C}$, with final construction of a dissociation curve. Pituitary and brain were obtained from 3 specimens in the temperature group at 201 and at $270 \mathrm{dph}$ respectively, and relative gene expression was calculated.

\subsection{Statistical analysis}

SPSS 19.0 software (IBM) was used to analyse significant differences among the various groups. The weight differences between same age male and female adult $A$. davidianus was analyzed by independent samples $t$-test. When Levene test gave $\mathrm{p}<$ 0.05 , signifcant differences were assumed. Conversely, equal variances were not assumed with $\mathrm{p}<$ 0.05 . In 2-tailed tests, the 2 groups sampled were considered significantly different at $p<0.05$. Differences of mortality rate and sex ratios at different temperatures and various hormone concentrations were analysed using chi-square test after data weight case followed by Fisher's exact test. Results were considered significant at $\mathrm{p}<0.05$. Difference in body lengths and body weights caused by temperature and hormone treatment and gene expression were analysed by one-way ANOVA, followed by Duncan's test. Results were considered significant at $\mathrm{p}<0.05$.

\section{RESULTS}

\subsection{Gonad development}

To observe gonad development and determine the time of sex differentiation, larvae of different ages were examined microscopically. At $48 \mathrm{dph}$, the germ cell was surrounded by somatic cells (Fig. 1A). At $62 \mathrm{dph}$, the size of the gonad had increased, with an

Fig. 1. Histology sections of the developing gonads of $A n$ drias davidianus. (A) $48 \mathrm{~d}$ post-hatching (dph); (B) $62 \mathrm{dph}$; (C) $98 \mathrm{dph}_{\text {; }}$ (D) $130 \mathrm{dph}_{i}$ (E) $170 \mathrm{dph}$ (F): ovary $210 \mathrm{dph}$ (G) testis $210 \mathrm{dph}$; $(\mathrm{H})$ : ovary $270 \mathrm{dph}$ (I) testis $270 \mathrm{dph}_{\text {; }}(\mathrm{J})$ : ovary $360 \mathrm{dph}$; (K) testis $360 \mathrm{dph}$ (L) ovary $545 \mathrm{dph}$ (M) testis $545 \mathrm{dph}$; $(\mathrm{N})$ ovary $3 \mathrm{yr}$ old; $(\mathrm{O})$ testis $3 \mathrm{yr}$ old. GC: germ cell; SC: somatic cell; GrC: granulosa cells; PF: primordial follicle; SL: seminiferous lobule; SP: spermatogonia; FC: follicular cavity; SeC: Sertoli celli PS: primary spermatocyte; Oo: oocyte. Scale bars are $10 \mu \mathrm{m}$ in $(\mathrm{A}-\mathrm{C}), 50 \mu \mathrm{m}$ in (D-M), $100 \mu \mathrm{m}$ in $(\mathrm{N}, \mathrm{O})$ increasing number of germ cells, but no structure changes (Fig. 1B). At 98 dph, the gonad was further increased in size, with the proliferation of germ cells and somatic cells, and the germ cells were dissociated from the cortex, suggesting beginning of sex differentiation (Fig. 1C). At 130 and 170 dph, (Fig. 1D,E) the quantity of somatic cell had increased. At $210 \mathrm{dph}$, the primordial follicle and spermatocyte were visible in ovary and testis, respectively. Germ cells were deeply stained and surrounded by granulosa cells (Fig. 1F). Testes at this stage contained spermatogonia and primary spermatocytes surrounded by Sertoli cells (Fig. $1 \mathrm{G})$. At $270 \mathrm{dph}$, the oocyte was clearly visible in the ovary and a seminiferous lobule was formed in the testis (Fig. 1H,I). At $360 \mathrm{dph}$, the gonads were larger, and the shape altered from a thin thread to flat. Oocytes were larger, and the follicular cavity had formed (Fig. 1J). Oocytes and spermatogonia matured from $360 \mathrm{dph}$ to 3 yr post-hatching (Fig. 1K-O).

\subsection{Mortality rate and sex ratio}

Mortality rate was calculated relative to temperature (Table S2 in the Supplement). We found 100\% mortality at $30^{\circ} \mathrm{C}$ (Fig. 2). The mortality rate was significantly higher at $24^{\circ} \mathrm{C}$ and $28^{\circ} \mathrm{C}(17.71 \%$ and

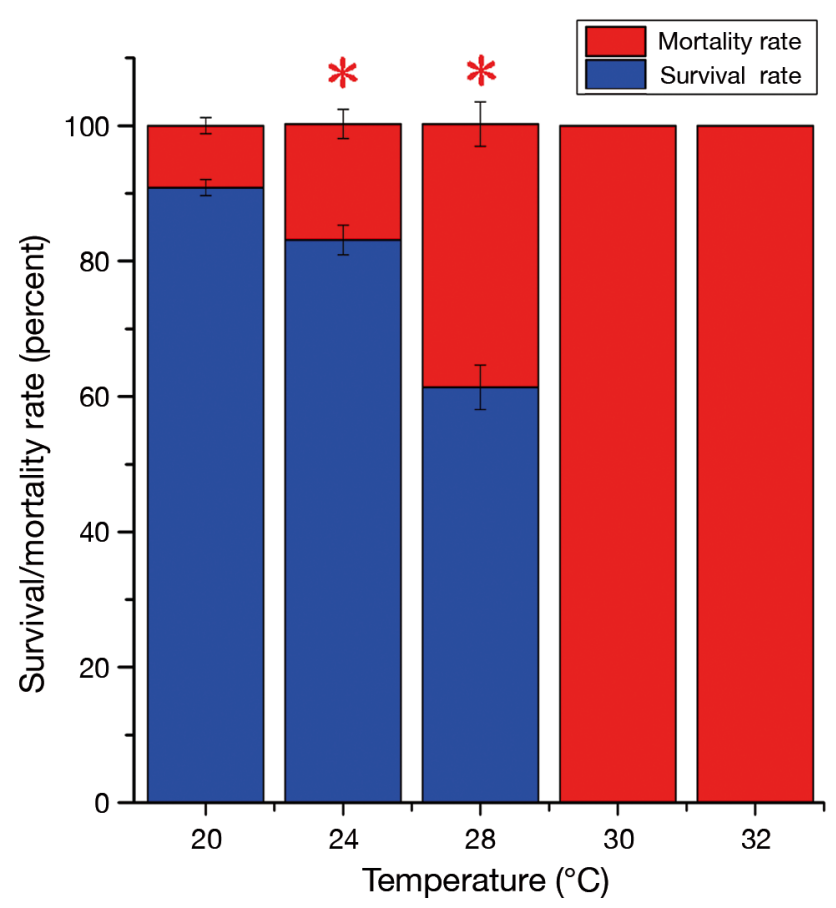

Fig. 2. Mortality rate of Andrias davidianus relative to water temperature. The red asterisk indicates a significant difference based on chi-square test between experimental and control groups $(\mathrm{p}<0.05)$ 
$40.63 \%)$ than at $20^{\circ} \mathrm{C}(9.37 \%)$ (Table S2) (p < 0.05). At $28^{\circ} \mathrm{C}$, the proportion of males was significantly higher $(66.06 \%)$ (Table S3) than at $24^{\circ} \mathrm{C}(50 \%)$ and $20^{\circ} \mathrm{C}(50 \%)(\mathrm{p}<0.05)$ (Fig. 3A). The sex ratio with respect to hormone exposure showed that estrogen induced feminization, while methyltestosterone had no effect (Fig. 3B). Depending on concentration, the mean proportion of females in larvae exposed to estrogen ranged from $81.1-100 \%$ and was significantly higher than in the control group (50\%) (p < 0.05) (Table S4). Additionally, in larvae treated with methyltestosterone sex ratios did not deviate from 1:1 (Table S4) ( $\mathrm{p}>0.05)$.

\subsection{Growth analysis}

Males grew more rapidly and to a larger size, increasing from (mean \pm SE) $5.44 \pm 0.73$ to $9.13 \pm 1.03 \mathrm{~kg}$, compared to females that grew from 4.15 \pm 0.42 to $7.01 \pm 0.72 \mathrm{~kg}$ over the $4 \mathrm{yr}$ study period (Table 1). Calculation of RGR showed males to significantly grow faster than females with $\sim 30 \%$ at each period $(\mathrm{p}<0.05)$.

Body weights and body lengths were monitored from $47 \mathrm{dph}$ to $3.5 \mathrm{yr}$ post-hatching. Mean body length increased from $5.12 \pm 0.21 \mathrm{~cm}$ at $47 \mathrm{dph}$ to $36.2 \pm 2.86 \mathrm{~cm}$ at $3.5 \mathrm{yr}$ post-hatching (Table S5) (Fig. 4A). From 47 to $345 \mathrm{dph}$, mean body weight gradually increased from $1.14 \pm 0.15$ to $33.75 \pm$ $11.92 \mathrm{~g}$, and subsequently sharply increased to $283.03 \pm 61.20 \mathrm{~g}$ at $3.5 \mathrm{yr}$ post-hatchingt (Table S5). Expression of $G H$ in pituitary and GHR and IGF-1 in brain exhibited a similar pattern, with a significant

Table 1. Body weight ( $\pm \mathrm{SE}$ ) of Andrias davidianus from ages 9 to $12 \mathrm{yr} . \mathrm{N}=$ number of specimens. ${ }^{*}$ indicates significant difference $(\mathrm{p}<0.05)$ between female and male weights by independent samples $t$-test. RGR: relative growth rate

\begin{tabular}{|lcccccc|}
\hline \multirow{2}{*}{ Age $(\mathrm{yr})$} & \multicolumn{2}{c}{ Female } & & \multicolumn{2}{c|}{ Male } & \multirow{2}{*}{ RGR } \\
\cline { 2 - 3 } & \multirow{2}{*}{$\mathrm{N}$ Mean weight $(\mathrm{kg})$} & & N Mean weight $(\mathrm{kg})$ & \\
\hline 9 & 113 & $4.15 \pm 0.42$ & & 84 & $5.44 \pm 0.73$ & $31.08 \%^{*}$ \\
10 & 185 & $5.28 \pm 0.76$ & & 49 & $6.97 \pm 0.86$ & $32.01 \%^{*}$ \\
11 & 276 & $6.67 \pm 0.88$ & & 68 & $8.81 \pm 1.12$ & $32.08 \%^{*}$ \\
12 & 263 & $7.01 \pm 0.72$ & & 135 & $9.13 \pm 1.03$ & $30.24 \%^{*}$ \\
\hline
\end{tabular}
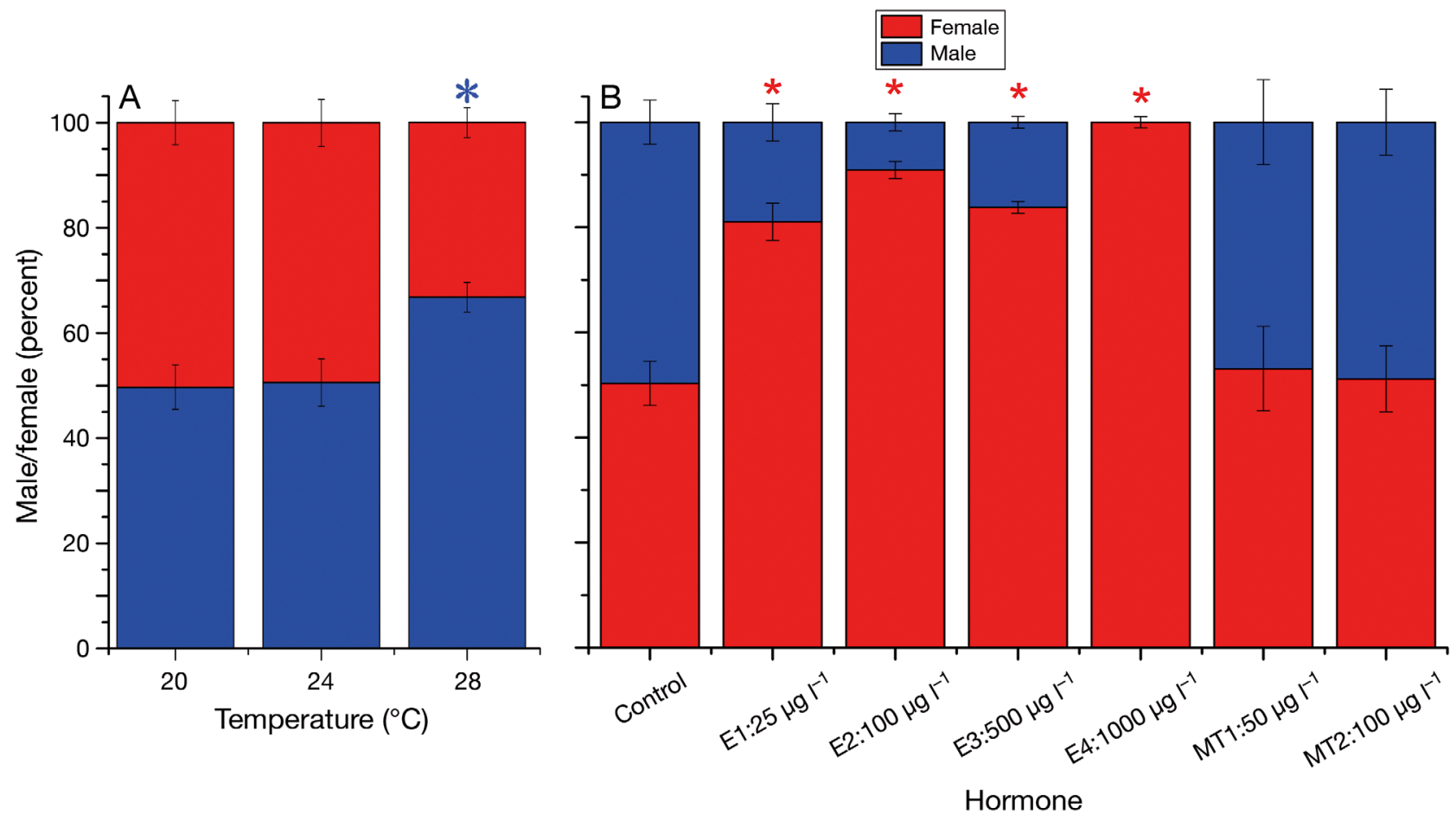

Fig. 3. (A) Effect of temperature on sex ratio of Andrias davidianus. (B) Sex ratio of A. davidianus after hormone treatment with estradiol or methyltestosterone. The blue asterisk indicates a significant difference in \% males using chi-square test between experimental group and control group ( $\mathrm{p}<0.05)$. The red asterisk indicates a significant difference in $\%$ females using chi-square test between experimental group and control $(\mathrm{p}<0.05)$. The A. davidianus larvae were treated by concentration of $17 \beta$-estradiol (E) and 17 $\alpha$-methyltestosterone (MT) as follows: E1: $25 \mu \mathrm{g} \mathrm{l^{-1 }}, \mathrm{E} 2: 100 \mu \mathrm{g} \mathrm{l^{-1 }}, \mathrm{E} 3: 500 \mu \mathrm{g} \mathrm{l^{-1 }}$, E4: $1000 \mu \mathrm{g} \mathrm{l^{-1 }}$, MT1: $50 \mu g \mathrm{l}^{-1}$, MT2: $100 \mu \mathrm{g} \mathrm{l^{-1 }}$ 
(6) ұчбіпэ Кров

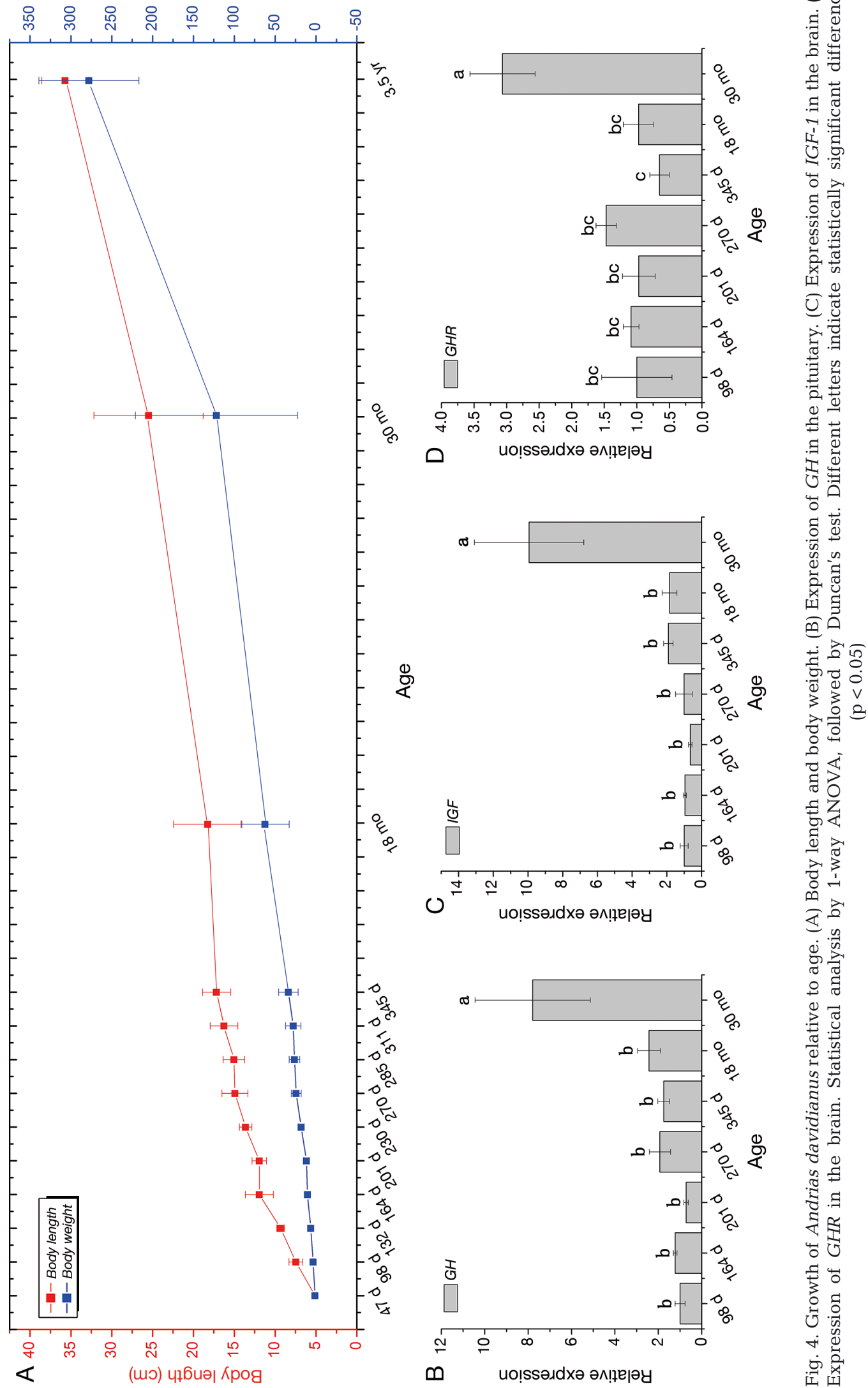


expression at 30 mo (Fig. 4) which was consistent with the weight increasing.

\subsection{Effect of temperature and sex hormone exposure on growth}

To assess the effect of temperature on growth performance, growth was measured during and following temperature exposures (Tables S6 \& S7). Mean body length was significantly lower at $28^{\circ} \mathrm{C}$ than in the $20^{\circ} \mathrm{C}$ control group at the assessed ages $(\mathrm{p}<0.05)$ (Fig. 5A). Mean body length at $24^{\circ} \mathrm{C}$ was greater than in the control group at $201 \mathrm{dph}$, but not significantly different ( $p>0.05$ ) (Fig. 5A). Body weight at $28^{\circ} \mathrm{C}$ was significantly lower than in the control group at all monitoring times ( $\mathrm{p}<0.05)$, except 132 and $345 \mathrm{dph}$. At $24^{\circ} \mathrm{C}$, body weight was significantly greater than seen in the control group from $230 \mathrm{dph}$ $(\mathrm{p}<0.05)$. Body weight at $28^{\circ} \mathrm{C}$ increased slowly; when water was returned to ambient temperature at $240 \mathrm{dph}$, weight increased sharply, and no difference was observed between 240 and 345 dph ( $p>0.05$ ). Body weight at $24^{\circ} \mathrm{C}$ showed the opposite pattern from that at $28^{\circ} \mathrm{C}$.

Mean body length of all hormone-exposed groups was significantly lower than in the control group from $164 \mathrm{dph}(\mathrm{p}<0.05)$ (Fig. 5C). Body weight was also lower with sex hormone exposure, and a similar profile was exhibited (Fig. 5D). During hormone exposure, body length and especially body weight increased slowly. When hormone exposure ceased, body length and especially body weight sharply increased (Fig. 5D) (Tables S8 \& S9).

\subsection{Effect of temperature on growth-related gene expression}

The expression level of growth-related genes was evaluated during and following temperature exposures. Expression of $G H$ in the pituitary and $G H R$ in the brain was significantly inhibited at temperatures of $24^{\circ} \mathrm{C}$ and $28^{\circ} \mathrm{C}(\mathrm{p}<0.05)$, while no difference was detected in IGF-1 in the brain during the temperature trial $(\mathrm{p}>0.05$, Fig. 6). After cessation of the temperature exposure, the expression level of the 3 genes was significantly higher in the group formerly at $24^{\circ} \mathrm{C}(\mathrm{p}<0.05)$ than in the control group, while no significant difference from controls was observed in the former $28^{\circ} \mathrm{C}$ group ( $p>0.05$, Fig. 6).

\section{DISCUSSION}

The effects of temperature and sex steroid exposure on sex ratio and growth rate have been studied in many species (Chardard et al. 1995, Wallace et al. 1999, Nakamura 2009, Olmstead et al. 2010). How temperature and sex steroid exposure affect the sex ratio and growth rate of Andrias davidianus is unclear. In the present study, we monitored gonad development to determine the time of initiation of sex differentiation. The results showed proliferation of germ cells at approximately $98 \mathrm{dph}$ suggesting the beginning of sex differentiation. In Euphlyctis cyanophlyctis gonad size was reported to have significantly increased at tadpole stage 27 due to the proliferation of germ cells and somatic cells, and the germ cell was pushed to the periphery. At this stage, gonad differentiation was evident by the initiation of meiosis in the oogonia (Phuge \& Gramapurohit 2013). In Xenopus laevis, gonads were formed at stage 51 to 54 when the primordial germ cells (PGC) were migrating into the medullary region (Villalpando \& Merchant-Larios 1990). 100\% sex reversal was induced when estradiol benzoate was applied before translocation of PGC from gonadal epithelium into the medullary region (Villalpando \& MerchantLarios 1990).

In the present study, we found that high temperature induced individuals to become males. In the wild, the stage of sex differentiation generally occurs in winter, when the salamanders inhabit caves and subterranean rivers with an ambient temperature of $13-19^{\circ} \mathrm{C}$. Studies of other species have shown that when larvae are reared outside their optimal temperature range the sex ratio is imbalanced. Rana sylvatica larvae reared at $32^{\circ} \mathrm{C}$ produced $50 \%$ males with the remainder exhibiting varying degrees of masculinized ovaries (Witschi 1929).

We observed sex ratio alterations in A. davidianus larvae exposed to sex hormones. In most anurans and all urodeles studied feminization is caused by estradiol but no masculinization by testosterone has been noticed (Wallace et al. 1999). Pleurodeles waltl larvae immersed in 50-100 $\mathrm{Mg}^{-1}$ estradiol became female or intersex, while lowdose testosterone had no sex reversal effect, but a dose exceeding $5 \mu \mathrm{g} \mathrm{l}^{-1}$ testosterone caused feminization or intersex (Gallien 1954). Xenopus laevis tadpoles exposed to $50 \mu \mathrm{g} \mathrm{l}^{-1}$ estradiol were all altered to female, although some lacked oviducts (Chang \& Witschi 1955). In contrast, Rana nigromaculata and $R$. japonica can be masculinized by testosterone and are unaffected by estradiol (Wal- 

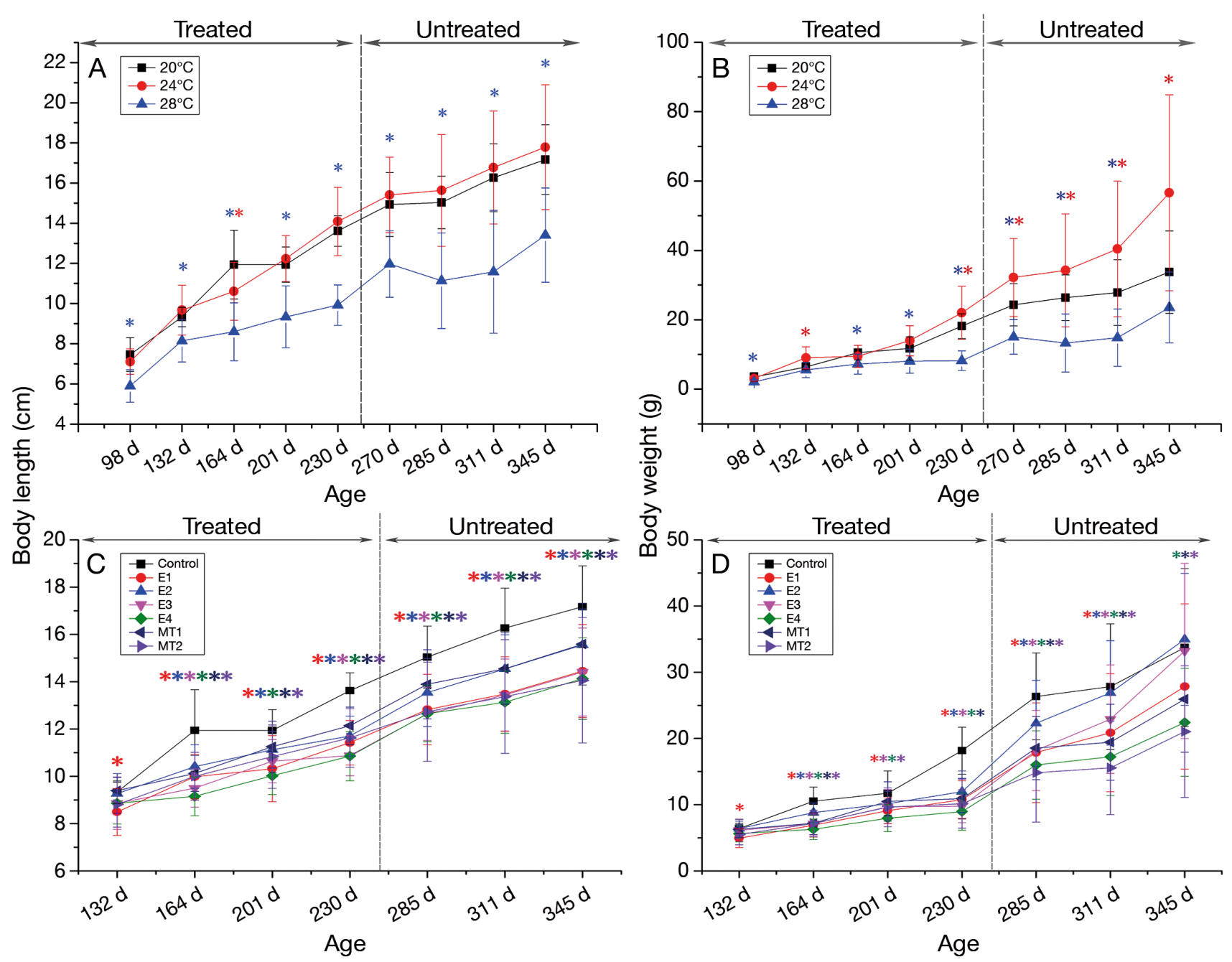

Fig. 5. Growth characteristics of Andrias davidianus at different temperatures and sex steroid exposure at different ages. (A) Body length of $A$. davidianus with temperature exposure. (B) Body weight of $A$. davidianus with temperature exposure. (C) Body length of $A$. davidianus with sex steroid exposure. (D) Body weight of $A$. davidianus with sex steroid exposure. Abbreviations as defined in Fig. 3. Different colored asterisks indicate statistically significant differences in growth performance using chi-square test between the corresponding experimental group and control group $(\mathrm{p}<0.05)$
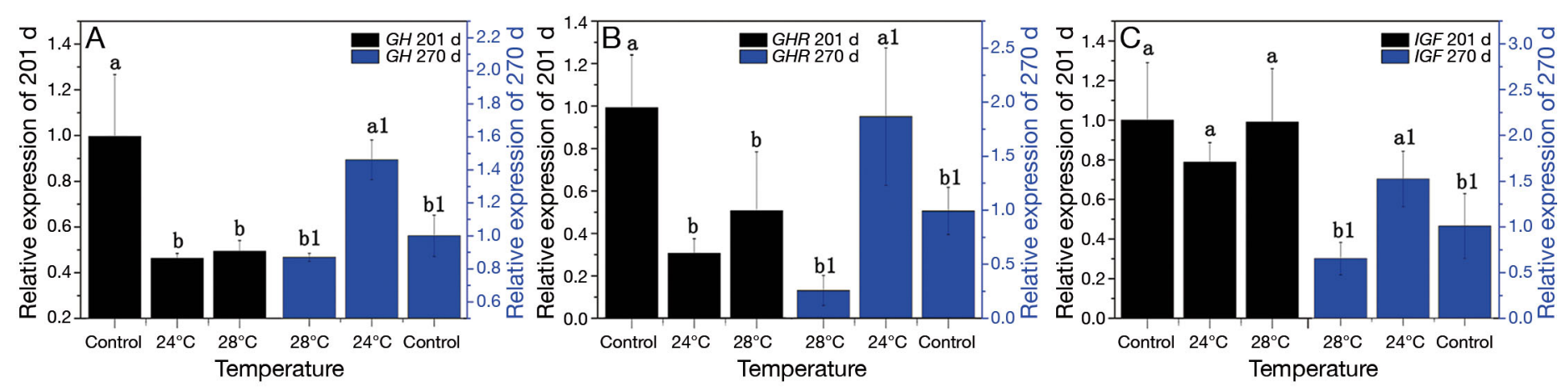

Fig. 6. Expression of growth-related gene during temperature exposure. (A) Expression of GH in the pituitary at 201 days posthatching (dph, d) and untreated at $270 \mathrm{dph}$. (B) Expression of GHR in the brain at $201 \mathrm{dph}$ and untreated at $270 \mathrm{dph}$. (C) Expression of $I G F-1$ in the brain at $201 \mathrm{dph}$ and untreated at $270 \mathrm{dph}$. Statistical analysis by 1 -way ANOVA, followed by Duncan's test. Different letters indicate statistically significant differences at identical developmental stage but different temperature $(\mathrm{p}<0.05)$ 
lace et al. 1999). $R$. pipiens tadpoles can be masculinized by testosterone and feminized by estradiol (Richards \& Nace 1978).

We observed growth dimorphism between male and female salamanders. In studies of Anura and Urodela, Shine (1979) estimated that in 530 of 589 frog species $(90 \%)$ females are larger than males, males are larger than females only in 18 species $(3 \%)$, and sexes are similar in size in 41 species (7\%). In 79 salamander species females are larger than males in $48(61 \%)$, males larger in $15(19 \%)$, and no dimorphism is seen in 16 (20\%) (Kupfer 2007). Many species exhibit a sex-dependent dimorphic growth pattern (Park et al. 2004, Chen et al. 2008). We found that growth-related gene $(G H, G H R$, and IGF-1) expression profiles were strongly consistent with growth characteristics, suggesting that the genes might be related to growth. The further growth of $A$. davidianus was assessed during and after the temperature trial. The results showed that growth was inhibited at a temperature of $28^{\circ} \mathrm{C}$ and promoted at a temperature of $24^{\circ} \mathrm{C}$. In an earlier study (data not shown), we deduced the optimal temperature for salamander to growth to be $20^{\circ} \mathrm{C}$ according to the temperature of inhabited caves $\left(\sim 20^{\circ} \mathrm{C}\right)$, but there was no supporting experimental data. The present study provides the experimental data to estimate the optimal temperature for growth of $A$. davidianus at $24^{\circ} \mathrm{C}$, which we expect to be the ideal temperature for farming of the giant salamander.

The expression of $G H$ and $G H R$ was significantly lower than in the controls at $24^{\circ}$ and $28^{\circ} \mathrm{C}$ during the high exposure stage (at $201 \mathrm{dph}$ ). When the temperature was returned to ambient values (at $270 \mathrm{dph})$, a significant increase in $G H$ and $G H R$ expression was observed in the former $24^{\circ} \mathrm{C}$ group, but no difference was noted in the $28^{\circ} \mathrm{C}$ group. A temperature of $28^{\circ} \mathrm{C}$ was associated with lower growth and $24^{\circ} \mathrm{C}$ with higher growth. The expression pattern of $G H$ and $G H R$ was consistent with the growth profile. The expression of IGF-1 was not significantly different from the control group during the high temperature exposure (at $201 \mathrm{dph}$ ), while the expression profile was similar to that of $G H$ and $G H R$ after the temperature was returned to ambient values (at $270 \mathrm{dph}$ ). The results suggested that $G H$ and $G H R$ were more strongly related to the growth of the salamander. These results have implications for the rearing of A. davidianus. At water temperatures outside the optimal range, feed consumption, enzyme activity, and feed conversion have been reported to be sig- nificantly affected (Wildhaber \& Crowder 1990, Neverman \& Wurtsbaugh 1994, Ji et al. 1996, Michalsen et al. 1998, Yee \& Murray 2004). When energy intake exceeds energy expenditure, weight increases. Energy intake and expenditure are both affected by temperature (Diana 1995).

Sex hormones not only altered the sex ratio, but were also shown to inhibit growth. Growth was significantly inhibited during treatment and sharply increased when treatment ceased. A previous study reported that sex hormones affect body growth by modulating the $G H$ signaling pathway (Fernández-Pérez et al. 2016). Estradiol and testosterone can modulate $G H$ action by regulating pituitary GH secretion (Kerrigan \& Rogol 1992, Mode $\&$ Gustafsson 2006). In mice, androgens may regulate the male skeleton through a stimulation of androgen receptors or estrogen receptors (Vidal et al. 2000).

In conclusion, the present study quantified $A$. davidianus growth sex dimorphism and determined the time of initiation of sex differentiation. Phenotypic sex and growth can be influenced by temperature and sex hormones during early development. Expression of growth-related genes agreed with the growth profile during and after treatment. Although the study did not elucidate the mechanisms involved in sex differentiation and growth in A. davidianus, the results reinforce the hypothesis that water temperature and some sex hormones (estradiol but not methyltestosterone) can modify both gonad differentiation and growth in Urodela. Further study to assess environmental factors and the underlying mechanisms is required to establish a rearing protocol for production.

Acknowledgements. This work was supported by the National Nature Science Foundation of China (grant no. 31502155), and a National Nonprofit Institute Research Grant (2017JBF0205), and a National Nonprofit Institute Research Grant from the Freshwater Fisheries Research Center, the Chinese Academy of Fishery Sciences (grant no. 2015JBFM40).

\section{LITERATURE CITED}

Asayama S, Miyamori H (1957) Responses of larval gonads in Hynobius nebulosus to the administration of estrogen. J Inst Polytech Osaka City, Univ Ser D 8:128-137

* Burns RK (1938) The effects of crystalline sex hormones on sex differentiation in amblystoma. I. Estrone. Anat Rec (Hoboken) 71:447-467

Burns RK (1939) The effects of crystalline sex hormones on sex differentiation in amblystoma. II. Testosterone propionate. Anat Rec (Hoboken) 73:73-93 
Chang CY, Witschi E (1955) Breeding sex-reversed males of Xenopus laevis Daudin. Proc Soc Exp Biol Med 89: 150-152

Chardard D, Desvages G, Pican C, Dournon C (1995) Aromatase activity in larval gonads of Pleurodeles walt (Urodele Amphibia) during normal sex differentiation and during sex reversal by thermal treatment effect. Gen Comp Endocrinol 99:100-107

* Chen SL, Deng SP, Ma HY, Tian YS and others (2008) Molecular marker-assisted sex control in half-smooth tongue sole (Cynoglossus semilaevis). Aquaculture 283: $7-12$

Diana JS (1995). Biology and ecology of fishes. Biological Sciences Press, New York, NY

* Dournon C, Houillon C (1984) Démonstration génétique de l'inversion fonctionelle du phénotype sexuel femelle sous l'action de la température d'élevage chez l'Amphibien Urodèle: Pleurodeles waltlii Michah [sic]. Reprod Nutr Dev 24:361-378

* Dournon C, Houillon C (1985) Thermosensibilité de la différenciation sexuelle chez l'Amphibien Urodèle Pleurodeles waitlii Michah [sic]. Conditions pour obtenir l'inversion du phénotype sexuel de toutes les femelles génétiques sous l'action de la température d'élevage. Reprod Nutr Dev 25:671-688

Fernández-Pérez L, de Mirecki-Garrido M, Guerra B, Díaz M, Díaz-Chico JC (2016) Sex steroids and growth hormone interactions. Endocrinol Nutr 63:171-180

Gallien L (1954) Inversion expérimentale du sexe sous l'action des hormones sexuelles chez le triton, Pleurodeles waltlii Michah [sic]. Analyse des conséquences génétiques. Bull Biol Fr Belg 88:1-51

Gallien L, Collenot A (1960) Inversion of the sexual phenotype (feminization) of Triturus helveticus Raz. and Triturus alpestris Laur, following gynogenous treatment by estradiol benzoate administered during the larval stage. C R Hebd Seances Acad Sci 250:926-928

Gao KQ, Shubin NH (2003) Earliest known crown-group salamanders. Nature 422:424-428

*Hayes TB (1998) Sex determination and primary sex differentiation in amphibians: genetic and developmental mechanisms. J Exp Zool 281:373-399

Hsü CY, Yü NW, Liang HM (1971) Induction of sex reversal in female tadpoles of Rana catesbeiana by temperature treatment. Endocrinol Jpn 18:243-251

$\mathrm{Hu}$ Q, Meng Y, Tian H, Chen S, Xiao H (2015) Cloning, expression of, and evidence of positive election for, the prolactin receptor gene in Chinese giant salamander (Andrias davidianus). J Exp Zool B Mol Dev Evol 324: 707-719

$\mathrm{Hu}$ Q, Xiao H, Tian H, Meng Y (2017) Identification and expression of cytochrome P450 genes in the Chinese giant salamander Andrias davidianus. Theriogenology 95:62-68

* Ji X, Du W, Sun P (1996) Body temperature, thermal tolerance and influence of temperature on sprint speed and food assimilation in adult grass lizards, Takydromus septentrionalis. J Therm Biol 21:155-161

Ji XS, Liu HW, Chen SL, Jiang YL, Tian YS (2011) Growth differences and dimorphic expression of growth hormone (GH) in female and male Cynoglossus semilaevis after male sexual maturation. Mar Genomics 4:9-16

Kerrigan JR, Rogol AD (1992) The impact of gonadal steroid hormone action on growth hormone secretion during childhood and adolescence. Endocr Rev 13:281-298
Kupfer A (2007) Sexual size dimorphism in amphibians: an overview. In: Fairbairn DJ, Blanckenhorn WU, Székely T (eds) Sex, size and gender roles: evolutionary studies of sexual size dimorphism. Oxford University Press, Oxford, p 50-59

Michalsen K, Ottersen G, Nakken O (1998) Growth of northeast Arctic cod (Gadus morhua L.) in relation to ambient temperature. ICES J Mar Sci 55:863-877

Mode A, Gustafsson JÅ (2006) Sex and the liver-a journey through five decades. Drug Metab Rev 38:197-207

Nakamura M (2009) Sex determination in amphibians. Semin Cell Dev Biol 20:271-282

Neverman D, Wurtsbaugh WA (1994) The thermoregulatory function of diel vertical migration for a juvenile fish. Oecologia 98:247-256

Ohta S (1987) Sex determining mechanism in Buergeria buergeri (Schlegel). II. The effects of sex hormones on the differentiation of gonads and the offspring of sexreversed females. Sci Rep Lab Amph Biol 9:213-238

Olmstead AW, Lindberg-Livingston A, Degitz SJ (2010) Genotyping sex in the amphibian, Xenopus (Silurana) tropicalis, for endocrine disruptor bioassays. Aquat Toxicol 98:60-66

Padoa E (1936) Effetto paradossale (mascolinizzazione) sulla differenziazione sessuale di girini Rana esculenta trattaticon ormone follicolare. Monit Zool Ital 47: 285-289

Padoa E (1943) Il differenziamento del sesso invertito mediante la somministrazione di ormoni sessuali e corticosurrenali. Ricerche con diidrofollicolina, progesterone e acetato di desossicorticosterone, in Rana esculenta. PSZNI: Mar Ecol 19:185-232

* Park IS, Kim JH, Cho SH, Kim DS (2004) Sex differentiation and hormonal sex reversal in the bagrid catfish Pseudobagrus fulvidraco (Richardson). Aquaculture 232: 183-193

พ Phuge SK, Gramapurohit NP (2013) Gonadal sex differentiation, development up to sexual maturity and steroidogenesis in the skipper frog, Euphlyctis cyanophlyctis. Gen Comp Endocrinol 181:65-71

Piquet J (1930) Détermination du sexe chez les batraciens en fonction de la température. Rev Suisse Zool 37:173-281

Richards CM, Nace GW (1978) Gynogenetic and hormonal sex reversal used in tests of the XX-XY hypothesis of sex determination in Rana pipiens. Growth 42:319-331

* Shine R (1979) Sexual selection and sexual dimorphism in the Amphibia. Copeia 1979:297-306

Vidal O, Lindberg MK, Hollberg K, Baylink DJ and others (2000) Estrogen receptor specificity in the regulation of skeletal growth and maturation in male mice. Proc Natl Acad Sci USA 97:5474-5479

*Villalpando I, Merchant-Larios H (1990) Determination of the sensitive stages for gonadal sex-reversal in Xenopus laevis tadpoles. Int J Dev Biol 34:281-285

Wallace H (1987) Abortive development in the crested newt Triturus cristatus. Development 100:65-72

Wallace H, Wallace BM (2000) Sex reversal of the newt Triturus cristatus reared at extreme temperatures. Int J Dev Biol 44:807-810

*Wallace H, Badawy GMI, Wallace BMN (1999) Amphibian sex determination and sex reversal. Cell Mol Life Sci 55: 901-909

Wang HP (2006) Effect of temperature on development of tadpole of Chinese forest frog (Rana chensinensis). J Shaanxi Inst Educ (China) 22:81-84 
Wang HP, Wang LZ (2008) Research progress in thermal biology of Rana chensinensis. Sichuan J Zool (China) 27: 478-480

Wang LZ, Li XC, Zhang CB (2005) Temperature effect on development of tadpoles of Bufo gargarizans and Rana chensinensis. Sichuan J Zool (China) 24: 355-358

Wildhaber ML, Crowder LB (1990) Testing a bioenergeticsbased habitat choice model: bluegill (Lepomis macrochirus) responses to food availability and temperature. Can J Fish Aquat Sci 47:1664-1671

Witschi E (1929) Studies on sex differentiation and sex determination in amphibians. III. Rudimentary her-

Editorial responsibility: Victor Benno Meyer-Rochow, Oulu, Finland maphroditism and Y chromosome in Rana temporaria. J Exp Zool 54:157-223

* Yang L, Meng Z, Liu Y, Zhang Y and others (2010) Growth hormone and prolactin in Andrias davidianus: cDNA cloning, tissue distribution and phylogenetic analysis. Gen Comp Endocrinol 165:177-180

Yang LP, Meng ZN, Liu XC, Zhang Y, Huang JH, Huang J, Lin HR (2011) AFLP analysis of five natural populations of Andrias davidianus. Acta Sci Natur Univ Sunyatseni (China) 18:270-273

Yee EH, Murray SN (2004) Effects of temperature on activity, food consumption rates, and gut passage times of seaweed-eating Tegula species (Trochidae) from California. Mar Biol 145:895-903

Submitted: December 6, 2018; Accepted: April 2, 2019 Proofs received from author(s): August 2, 2019 